\title{
Assessing the link between service innovation and performance in telecommunication industry
}

\author{
Ogunnaike, Olaleke Oluseye ${ }^{1, ~ *}$, Ibidunni, Stephen Ayodotun ${ }^{1}$, Adetowubo-King, Sunday ${ }^{2}$ \\ ${ }^{1}$ Department of Business Management, Covenant University, Ota, Ogun State, Nigeria \\ ${ }^{2}$ Department of Business Education, Tai Solarin college of Education, Ijebu Ode
}

\section{Email address:}

olaleke.ogunnaike@covenantuniversity.edu.ng (Ogunnaike, O. O.), ayodotun.ibidunni@covenantuniversity.edu.ng (Ibidunni, S. A.), adetowuboking@yahoo.com (Adetowubo-King, Sunday)

\section{To cite this article:}

Ogunnaike, Olaleke Oluseye, Ibidunni, Stephen Ayodotun, Adetowubo-King, Sunday. Assessing the Link between service Innovation and Performance in Telecommunication Industry. Science Journal of Business and Management. Vol. 2, No. 1, 2014, pp. 16-23.

doi: $10.11648 /$ j.sjbm.20140201.13

\begin{abstract}
Literature search has revealed that despite the dominance of services in modern economies, and their rapid growth worldwide, there are limited researches in the area of service innovation. This study attempted to bridge the gap by ascertaining the nature of relationship between innovation and firm performance. The study adopted a mixture of expost-facto and survey research design. The sources of data for the study were both primary and secondary. The research instrument was developed and it was subjected to both validity and reliability measures and was found to be valid and reliable for the study. Simple random sampling technique was adopted for the study. Three hypotheses were formulated and subjected to inferential statistical tests such as correlation and regression. It was discovered that service process innovation, service modification and service innovation structure are significantly related to firm performance. It was recommended that firms should put in place service innovation structure that is coupled with quality improvement practices in order to sustain and enhance its competitive advantage and customer patronage.
\end{abstract}

Keywords: Service Process Innovation, Service Modification, Service Innovation Structure and Performance

\section{Introduction}

Innovation is gaining increasing recognition as a major competitive weapon and occupying a major part of the corporate strategy of many firms across the globe (Bradshaw and Turner, 2008). A content analysis on the term "innovation" carried out within the organisational context is defined as the multi-stage process whereby organisations transform ideas into new and improved products, service or processes, in order to advance, compete, and differentiate themselves successfully in their marketplace (Baregheh et al, 2009). On a continuous basis, services are provided in all spheres of business, ranging from SMEs, joint ventures, consulting firms, internet services, transport, tourism, social welfare, telecommunication services and so on. From a broad perspective therefore, an aggregate of these services by individual companies serves as a major catalyst for economic growth and industrial development in any country. Statistical evidences reveal that the bulk of revenues of GNP of advanced industrialized countries "come from the production, distribution and trade of services" (Maffei,
Mager and Sangiorgi, 2005).

A comprehensive definition of service innovation was proposed by Van Ark et al (2003) when they said service innovation can be defined as a new or considerably changed service concept, client interaction channel, service delivery system or technological concept that individually, but most likely in combination, leads to one or more (re)new(ed) service functions that are new to the firm and do change the service/good offered on the market and do require structurally new technological, human or organisational capabilities of the service organisation. Service innovation is a competitive tool to surpass competitors in the service market. Innovation is the fundamental source of value creation and an important enabler of competitive advantage (Cinite, 2010).

In the Nigerian telecommunications industry for instance, there are a good number of service providers. These companies all strive to expand their market share, minimize costs, and be responsive to customer's needs, also to 
increase customer base, sales volume, and ultimately profit. As such, keeping services customer-oriented has become so huge a priority for these companies because customer needs are dynamic and constantly change as a result of social, technological, and environmental factors.

The role of service innovation to organisational performance through the provision of improved services which translates into consumer satisfaction and to a large extent is a determinant of long-term survival, market dominance, and improvement of organisational performance within a competitive business environment of any economy.

Despite the over eleven years of introduction of digital mobile communication technology in Nigeria, the telecommunications industry is still victimized by a number of cogent challenges. These challenges revolve: communication barrier between companies and customers, operation inefficiencies, cost inefficiencies, and other related service delivery problems which affect the competitiveness and overall performance of business organisations. The essence of adapting innovative service processes such as internet technology, automation of service delivery system, and toll-free communication as factors that help organisations overcome these problems have been analysed, documented, and reviewed in several literatures.

Also, bearing in mind the dynamic and competitive nature of the business environment coupled with customers continually coming up with numerous needs and requirements which they expect to be met, companies in the industry have to develop strategies geared at being customer-oriented. It will also be proper to set up a structure for employees to respond to customers' needs satisfactorily, constantly research and develop innovative programmes and other service innovation structures geared at response to customers. Organisation that fails to modify its products/services to suit current and prospective consumer-taste would be surpassed in terms of market demand and sales by competitors who identify such need to constantly apply changes that improve their products and make them current in the market. It is upon this background that this paper sets out to achieve the following objectives:

1. To ascertain if innovative service processes have significant effect on the performance of an organization

2. To ascertain if there is a significant relationship between service modification(innovation)and sales volume

3. To identify the significant relationship between service innovation structure and company's responsiveness to its customers.

\section{Literature Review}

Kotler et al (2002) defined services as products that consist of activities, benefits of satisfaction that are offered for sale that are essentially intangible and do not result in the ownership of anything. A more advanced definition might be the consideration of Ding, Susman and Waren (2006) which views a service as "An activity or series of activities of a more or less tangible nature that normally, but not necessarily, takes place in interaction between a customer and service employees and/or physical resources or goods and/or systems of the service provider, which are provided as solutions to customer problems". As defined by (Lovelock and Wirtz, 2007), services are economic activities offered by one party to another, most commonly employing time-based performance to bring about desired results in recipients themselves or in objects or other assets for which purchasers have responsibility. The definition emphasises that while customers expect to obtain value from their service purchases in exchange for their money, time and effort, this value comes from access to a variety of value-creating elements rather than from transfer of ownership.Service innovation is a significant mechanism for driving growth and structural change in an economy (European Commission, 2012). This is achieved through a transformational role in the overall business processes and models in a way that creates significant customer experience and improving the overall value chain.

Services are the result of a production activity that changes the conditions of the consuming units, or facilitate the exchange of products or financial assets (Pariag, 2009). These types of service may be described as transformation services and margin services respectively. Transformation services are outputs produced to order and typically consist of changes in the conditions of the consuming units realized by the activities of producers at the demand of the consumers. Transformation services are not separate entities over which ownership rights can be established. They cannot be traded separately from their production. By the time their production is completed, they must have been provided to the consumers. An important argument that supports the relevance of services draws from the fact that products alone are not sufficient to create the required customer satisfaction that dirves in their loyalty to a particular supplier (Bitner, Ostron and Morgan, 2007). Thereby making services a necessary requirement.

Stanton (1981) viewed services as those separately identifiable, especially intangible activities that provide want-satisfaction, and that are not necessarily tied down to the sale of a product or another service. To produce a service may or may not require the use of tangible goods. However, when such use is required, there is no transfer of the title (permanent ownership) to these tangible goods. We include such activities as medical care, entertainment, and repair services (but not medicines or repair parts purchased). The consumer of a service can take only temporary possession or make only temporary usage of any goods required in the production of the service. Unlike physical goods services are essentially intangible, but are also subject to transaction process just like goods. The unique nature of services emanates from several distinctive characteristics. These service characteristics include: intangibility, inseparability, heterogeneity, perishability. In an attempt to identify the levels of services, the value proposition of the service must address and integrate these service levels: core product and 
augmented services. Sasser et al(1978) described the core service level as the substantive service, which is best understood as the essential function of a service. The core product is the central component that supplies the principal, problem-solving benefits customers seek (Lovelock and Wirtz, 2007). Thus, transport solves the need to move a person or physical object from one location to another; and repair services restore a damaged of malfunctioning machine to good working order. Augmented services supplement the core product, both facilitating its use and enhancing its value and appeal (Lovelock and Wirtz, 2007). The extent and levels of supplementary services often play a role in differentiating and positioning the core product against competing services. Adding more supplementary elements or increasing the level of performance should be done in ways that enhance perceived value of the core product for prospective customers and enable the service provider to charge a higher price. Augmented services may be after-sales service for delivery and installation of facility equipment; and could also be room-services in a hotel.

As a process, Selman (2010) stated that a powerful way to think of innovation is that it means: intentionally 'bringing into existence' something new that can be sustained and repeated and which has some value or utility. That is, innovation is always related to some practical 'in-the-world' value. It is about making new tools, products or processes, bringing forth something 'new' which allows human beings to accomplish something they were not able to accomplish previously. Kotler et al., (2002) also defined innovation as a process of identifying, creating, and developing new product or service values that did not exist before in the marketplace.

\subsection{The Concept of Service Innovation}

Nählinder (2005) indicated that innovation is not always a change in a tangible product or the production process of such a product. It may also be a change in what we usually label a service. Most importantly, innovation is more than merely technical change. Nählinder (2005) further stated that services have been sadly invisible in the common discussion of innovation and even the existence of innovation in services has been questioned. Researchers of innovation in services sometimes even defend their existence. One reason for this neglect may be that it is difficult to conceptualise an innovation in an intangible service and even harder to see how such an innovation may have importance. While, for many people, the word "innovation" is immediately associated with large technological devices, such as the steam engine, electronic gadgets and technical advances. On the contrary, the concept of the word 'innovation' is more inclusive. Innovation is more than merely technical change. Some innovations are changes in technology but an innovation may also be an organisational change for example, or a service product.

Service innovation in the opinion of the European Commission (2012) "comprises new or significantly improved service concepts and offerings as such, irrespective of whether they are introduced by service companies or manufacturing companies, as well as innovation in the service process, service infrastructure, customer processing, business models, commercialisation (sales, marketing, delivery), service productivity and hybrid forms of innovation serving several user groups in different ways simultaneously.

A massive literature on services has demonstrated that service sectors are innovative although they do not have the same points of departure and tend to regard innovation in services differently compared to manufacturing sectors (Howells 2000). The concept of innovation in services however, is not limited to pure service firms alone but also extends to manufacturing firms that support their products with services (Lenfle, 2004). This is due most often to create a competitive distinction from other firms operating in the same industry and to offer need satisfying solution to customers.

Drawing from the views of Lenfle (2004) and Lovelock $\&$ Wirtz (2007), the concept of innovation in service is not limited to purely service firms alone but also extends to manufacturing firms that support their products with services. This is done most often to create a competitive distinction from other firms operating in the same industry and to offer need satisfying solutions to customers. There are many different ways for a service provider to be innovative. Below are some categories of service innovations. Major service innovations; which are new core products for markets that have not been previously defined. They usually include both new service characteristics and radical new processes.

Major process innovations; which consists of using new processes to deliver existing core products in new ways with additional benefits.

Product-line extensions; which are additions to current product-lines by existing firms. The first company in the market to offer such product may be seen as an innovator, the others are merely followers often acting defensively. These new services may be targeted at existing customers with different needs.

Process-line extensions; which are less innovative than product innovations, but often represent distinctive new ways of delivering existing products, either with the intent of offering more convenience and a different experience for existing customers or of attracting new customers who find the traditional approach unappealing.

Supplementary service innovations; which take the form of enhancing service elements to an existing core service, or of significantly improving an existing supplementary service.

Service improvements; which are the most common type of service innovation. They involve modest changes in the performance of current products, including improvements to the core product or to the existing supplementary services or both.

Style changes; represent the simplest type of innovation, typically involving no changes in either processes or performance. However, they are highly visible and may 
serve to motivate employees.

\subsection{Service Innovation as a Process}

A captivating way to describe the service process is to say: a series of activities in which "people are doing things for other people" (Fingar, 2009). Service as a process involves a line of activities that ensure the effective functioning of services (Bitner, Ostron and Morgan, 2007). It has often been pointed out that process innovation may be particularly helpful for firms since it has the advantages of efficiency and low risk. Innovation in process involves adopting new improved mediums of rendering services. Jeston and Neilis (2006) stated that successful organizations have an innovation process working its way through all levels of the organization. IFN and IBM (2007) opined that "succeeding through service innovation presents three key challenges: developing people with the skills and service mindset to become adaptive innovators; developing integrative systems research; and raising awareness among policy makers and key stakeholders". As noted by Fingar (2009), service processes are characterised by varying outcomes among knowledge workers, customization of the service, it is labour intensive, on demand "pull" of resources, simultaneous occurrence of production and consumption and the immediate consumption of the service.

\subsection{Theoretical Base of the Study}

\section{- Diffusion of Innovation Theory}

The diffusion theory was originated by Gabriel Tarde, a French lawyer and judge, alongside Neal Gross (1946-1948), Bruce Ryan who was a graduate assistant for Neal Gross, and The British and German-Austrian Diffusionists(Calvo and Rahrig, 1997). Diffusion of Innovations is a theory that analyses, as well as helps explain, the adaptation of a new innovation. In other words, it helps to explain the process of social change. An innovation is an idea, practice, or object that is perceived as new by an individual or other unit of adoption. The perceived newness of the idea for the individual determines his/her reaction to it (Rogers, 1995). In addition, diffusion is the process by which an innovation is communicated through selected channels over time among the members of a social system. Thus, according to Rogers (1995) the aforementioned definition contains four elements that are present in the diffusion of innovation process. These elements are: innovation, communication, time and the social system. Mass media channels of the communication process are more effective in creating knowledge of innovations, whereas interpersonal channels are more effective in forming and changing attitudes toward a new idea, and thus in influencing the decision to adopt or reject a new idea. Most individuals evaluate an innovation, not on the basis of scientific research by experts, but through the subjective evaluations of near-peers who have adopted the innovation.First, time is involved in the innovation-decision process: is the mental process through which an individual (or other decision-making unit) passes from first knowledge of an innovation to forming an attitude toward the innovation, to a decision to adopt or reject, to implement the new idea, and to confirm this decision. The second way in which time is involved in diffusion is in the innovativeness of an individual or other unit of adoption. Innovativeness is the degree to which an individual or other unit of adoption is relatively earlier in adopting new ideas than other members of a social system. The third way in which time is involved in diffusion is in rate of adoption. The rate of adoption is the relative speed with which an innovation is adopted by members of a social system. The rate of adoption is usually measured as the number of members of the system that adopt the innovation in a given time period.

\section{- $\quad$ The Demarcation Approach to Innovation in Services}

The demarcation approach, argues that due to the peculiarities of service products, innovation in services differ from innovation in manufacturing and must thus be treated as something which is different in kind. Whereas the assimilationist approach treats service sectors as odd manufacturing sectors, scholars of the demarcation approach assume that innovation in service sectors are of another type than the innovations taking place in manufacturing sectors.

Scholars of this perspective also tend to focus on differences between service sectors and manufacturing sectors and not on differences among various service sectors according to (Boden and Miles, 2000).

\section{- The Synthesis Approach to Innovation in Services}

The synthesis approach recognises that innovations taking place in service sectors may differ from innovations taking place in manufacturing sectors and findings on innovation in service sectors may enrich the concept of innovation in manufacturing. According to (Drejer 2004), the synthesis approach is still in its infancy, but she mentions Gallouj and Weinstein (1997) and Preissl (2000) as contributions to the synthesis approach.

The synthesis approach (which is also denoted the rainbow economy) sees services and manufacturing as intrinsic parts of the economy. The distinction between service sectors and manufacturing sectors is blurred since manufacturing sectors produce service products and service sectors sometimes produces goods products (Boden and Miles 2000).

\section{Research Methods}

The survey method of research was adopted. Opinions of the study population concerning the research topic were gathered by administering questionnaires that ask questions concerning the impact of service innovation on organisational performance to them. The ex-post facto method which involves the use of secondary data from the internet, journals, articles, and so on was also used. Relevant data were collected at the same instance therefore, a cross-sectional design was adopted as well. The study population consists of the number of employees in chosen 
Telecommunications Company, Nigeria with primary focus on a particular branch of the Company. The justification for this location draws from the fact the branch has the largest number of customer patronage. The study population include employees of genders, various age groups and educational qualifications, and employees at various levels of management. A sample of one hundred and fourteen (114) employees were administered with questionnaires out of the one hundred and sixty (160) employee population of the telecommunication firm as calculated using the Yard's formula. The convenience sampling technique was adopted, whereby the researchers selected a branch of the telecommunication company as the sample frame to represent the entirety of the company's branches nationwide based on the ease of accessibility and collection of data from the selected elements. Elements in the study population had equal chance of being selected at random without any specific selection criteria, therefore, the simple random technique was also used for this study. Of the one hundred and fourteen (114) employees administered with questionnaires, Ninety (90) questionnaires representing $78.95 \%$ were returned, and twenty-four (24) questionnaires representing $21.05 \%$ were not returned. The data used for this study was obtained from both primary and secondary sources. The primary data was gathered using questionnaire structured on the basis of the research hypothesis, which was presented to respondents to express their views, opinions, and observations. Secondary data on the other hand refers to already published information. The secondary data used to conduct this study were sourced from textbooks, journals, articles, earlier publications, encyclopaedia, and dictionaries. The questionnaire was divided in two broad categories. The first category is made up of Section 1 which deals with personal data of respondents. Their; sex, age group, educational qualification, position occupied in firm and years of work experience. The second category is the body of the questionnaire that includes all questions relevant to this research. It comprises of Sections 2, 3, and 4. Sections 2 and 3 consist of both negative and positive questions structured on the basis of the two constructs of this research study, i.e Service innovation and Organisational performance respectively. The likert-scale was used to measure opinions, where for positive questions (Strongly Agree $=5$, Agree $=4$, Undecided = 3, Disagree =2, Strongly Disagree $=1$ ), and for negative questions (Strongly Agree = 1 , Agree $=2$, Undecided $=3$, Disagree $=4$, Strongly Disagree $=5$ ). Finally, Section 4 in the second category of the research instrument is made up of two related open-ended questions. The reliability test indicated that the research instrument used for this study is highly reliable (at 0.745 ) as it was above the generally accepted reliability score of 0.7 .

\section{Data Analysis and Hypothesis Testing}

Three hypothesis were developed and sufficiently tested to cover the research work.

Hypothesis 1:

$\mathrm{H}_{0}$ : service process innovation has no significant effect on firm performance.

$\mathrm{H}_{1}$ : service process innovation has a significant effect on firm performance.

Table 1. Model Summary

\begin{tabular}{cccc}
\hline Model & R & R Square & Adjusted R Square \\
\hline 1 & $.721(\mathrm{a})$ & .519 & .485 \\
\hline
\end{tabular}

Table I. B ANOVA $(B)$

\begin{tabular}{|c|c|c|c|c|c|c|}
\hline Model & & Sum of Squares & Df & Mean Square & $\mathbf{F}$ & Sig. \\
\hline \multirow{3}{*}{1} & Regression & 37.192 & 6 & 6.199 & 14.952 & .000 (a) \\
\hline & Residual & 34.408 & 83 & .415 & & \\
\hline & Total & 71.600 & 89 & & & \\
\hline
\end{tabular}

The results from the tables above revealed that the extent to which the variance in firm performance can be explained by service process innovation is $51.9 \%$ i.e $(\mathrm{R}$ square $=0.519)$ at 0.0001 significance level. The significance level below 0.01 implies a statistical confidence of above 99\%. This implies that service process innovation has a significant effect on organisational performance. Thus, the decision would be to reject the null hypothesis $\left(\mathrm{H}_{0}\right)$, and accept the alternative hypothesis $\left(\mathrm{H}_{1}\right)$.

Hypothesis 2:

H0: There is no significant relationship between service modification and sales volume.

H1: There is a significant relationship between service modification and sales volume. 
Table 2. Correlations

\begin{tabular}{|c|c|c|c|}
\hline & & $\begin{array}{l}\text { The organisation modifies its product } \\
\text { offerings (services) frequently to suit } \\
\text { the needs of the customers }\end{array}$ & $\begin{array}{l}\text { In the last two years, your } \\
\text { organisation has experienced } \\
\text { steady increase in sales }\end{array}$ \\
\hline \multirow[t]{3}{*}{$\begin{array}{l}\text { The organisation modifies its product offerings } \\
\text { (services) frequently to suit the needs of the } \\
\text { customers }\end{array}$} & Pearson Correlation & 1 & $.408(* *)$ \\
\hline & Sig. (2-tailed) & & .000 \\
\hline & $\mathrm{N}$ & 90 & 90 \\
\hline \multirow[t]{3}{*}{$\begin{array}{l}\text { In the last two years, your organisation has } \\
\text { experienced steady increase in sales }\end{array}$} & Pearson Correlation & $.408(* *)$ & 1 \\
\hline & Sig. (2-tailed) & .000 & \\
\hline & $\mathrm{N}$ & 90 & 90 \\
\hline
\end{tabular}

The coefficient of determination is obtained using formula C.O.D $=\mathrm{r}^{2} \times 100 \%$

Where $r=$ Pearson Correlation

Thus;

C.O.D $=(0.408)^{2} \times 100 \%$

C.O.D $=0.19584 \times 100 \%$

C.O.D $=19.584 \%$

The Pearson correlation of $\mathrm{r}=0.408$ therefore implies $19.584 \%$ shared variance between service modification and sales volume.

The relationship between the variables (service modification and sales volume) was investigated using Pearson correlation coefficient. The results from table 4.3.3 above show that there is a significant positive correlation of
(0.408) between both variables at 0.0001 level of significance.

Thus, as obtained from the table $\{\mathrm{r}=0.408, \mathrm{p}<0.01, \mathrm{n}=$ $90\}$. Haven found out that there is a significant relationship between service modification and sales volume, we therefore reject the null hypothesis $\left(\mathrm{H}_{0}\right)$, and accept the alternative hypothesis $\left(\mathrm{H}_{1}\right)$.

Hypothesis 3:

$\mathrm{H}_{0}$ : A significant relationship does not exist between service innovation structure and company's responsiveness to its customers.

$\mathrm{H}_{1}$ : A significant relationship exists between service innovation structure and company's responsiveness to its customers.

Table 3. Correlations

\begin{tabular}{llll}
\hline & & $\begin{array}{l}\text { In terms of responsiveness to } \\
\text { customer requirement, your } \\
\text { organisation has been proactive }\end{array}$ & $\begin{array}{l}\text { Your organisation has } \\
\text { flexible policies }\end{array}$ \\
\hline $\begin{array}{l}\text { In terms of responsiveness to customer requirement, } \\
\text { your organisation has been proactive }\end{array}$ & Pearson Correlation & 1 \\
& Sig. (2-tailed) & \\
Your organisation has flexible policies & $\mathrm{N}$ & 90 \\
& Pearson Correlation & $.435(* *)$ \\
& Sig. (2-tailed) & .000 \\
\hline
\end{tabular}

The coefficient of determination is obtained using formula C.O.D $=\mathrm{r}^{2} \times 100 \%$

Where $\mathrm{r}=$ Pearson Correlation

Thus;

$$
\begin{aligned}
& \text { C. } O . D=(0.435)^{2} \times 100 \% \\
& \text { C.O.D }=0.18705 \times 100 \% \\
& \text { C. } O . D=18.705 \%
\end{aligned}
$$

The Pearson correlation of $\mathrm{r}=0.435$ therefore implies $18.705 \%$ shared variance between service innovation structure and company's responsiveness to its customers.

The relationship between the variables (service innovation structure and company's responsiveness to its customers.) was investigated using Pearson correlation coefficient. The results from table 4.3 .4 above show that there is a significant positive correlation of $(0.435)$ between both variables at 0.0001 level of significance. Thus, as obtained from the table $\{\mathrm{r}=0.435, \mathrm{p}<0.01, \mathrm{n}=90\}$. Haven found out that a significant relationship exists between service innovation structure and company's responsiveness to its customers, we therefore reject the null hypothesis $\left(\mathrm{H}_{0}\right)$, and accept the alternative hypothesis $\left(\mathrm{H}_{1}\right)$.

Results from the field survey analysis showed that service process innovation has a significant effect on organizational performance because it was observed that a company that adopts the use of internet technology in day-to-day operations, automation of service delivery, and uses toll-free communication as innovative service processes tend to perform very well. This analytical finding is consistent with that of (Hamel, 2011) who states that a company can't perform better or outgrow its competitors unless it can out-innovate them.

Secondly, it was discovered that a significant relationship 
exists between service modification and sales volume. Analytical results show that an organisation that modifies its product offerings (services) frequently to suit the needs of the customers would experience steady increase in sales.

Finally, this research was also able to ascertain that there exist a significant relationship between service innovation structure and company's responsiveness to its customers. A company that has innovation-based policies, flexible organizational structure, and little bottle-neck in decision-making was found out to be proactive in responding to customers' ever changing demands. This finding is therefore in accordance with that of (Berry et al, 2006) who found that companies that successfully create cultures that value innovation and develop innovation-based organisational structures will see a steady stream of incremental improvements, especially in reacting to dynamic market needs that help the bottom line.

\section{Conclusion and Recommendations}

The research study has contributed to our knowledge on the impacts of service innovation on organisational performance. The results demonstrate that service process innovation has a significant effect on organisational performance; likewise a significant relationship exists between service modification and sales volume, and service innovation structure and company's responsiveness to its customers. Therefore the following recommendations are made:

1. Companies should quick to out-innovate competitors in service processes in order to command better overall organisational performances.

2. In their quest to for an upward rising of sales volume, organisations should constantly make relevant modifications to their services offerings for it to be continually relevant in satisfying the ever-changing market needs.

3. Organisations should develop structure that value service innovation in order for management, staff, and other organisational elements to be swift in responding to customer requirements.

4. Companies should incorporate innovation in rendering services and in new product development with the aim to continuously improve on their services and products.

5. Organisations should hold on to innovation as this research has been able to establish that it is a key to increased sales and ultimately market share.

\section{References}

[1] Baregheh A., Rowley J., Sambrook S., (2009) "Towards a multidisciplinary definition of innovation", Management Decision, Vol. 47 Iss: 8, pp.1323 - 1339

[2] Berry, L.L., Shankar, V., Parish, J.T, Cadwallader, S., \& Dotzel, T. (2006). Creating New Markets Through Service Innovation. vol.47, no.2. Massachusetts: MIT Sloan
[3] Bitner, M.J., Ostrom, A.L., and Morgan, F.N. (2007) Service Blueprinting: A Practical Tool for Service Innovation. Innovation in Services Conference, Berkeley, April 26-28

[4] Boden, M. \& Miles, I. (2000). "Conclusions Beyond the Service Economy. In Services and the Knowledge Based Economy. London \& New York: Continuum

[5] Bradshaw, T. \& Turner, A. (2008) -Excellence in service innovation CBI/QinetiQ report on innovation in UK service sector businesses II, viewed 29 April 2011, http://www.cbi.org.uk/pdf/Excellenceinserviceinnovation.pd f>

[6] Calvo, A., \& Rahrig, K. (1997). Diffusion of Innovations. PHC 6500 Foundations of Health Education

[7] Cinite I. (2010), Services Innovation Understanding value creation in the 21 st Century, A research report retrieved from http://www.innovationcultures.com/pdf/EXTR_rep26_EMA IL.pdf

[8] Coombs, R. \& Miles, I. (1999). Innovation, Measurement and Services.: The New Problematique in: J.S. Metcalfe \& I. Miles (Eds.), Innovation Systems in the Service Economy. Norwell. Massachusetts: Kluwer Academic Publishers

[9] Drejer, I. (2004). Identifying Innovation in Surveys of Services. A Schumpeterian Perspective. Research Policy. 33(3), pp. 551-562

[10] Fingar T. (2009), "Reducing Uncertainty: Intelligence and National Security Using Intelligence to Anticipate Opportunities and Shape the Future" Lecture at Stanford University, October 21, retrieved from http://iis-db.stanford.edu/evnts/5859/lecture_text.pdf

[11] Gallouj, F., \& Weinstein, O. (1997). Innovation in Services. Research Policy. Cheltenham: Crown

[12] Hamel (Harvard Business Review). Retrieved May, 2011 from www.bptrends.com

[13] Howells, J. (2000). Innovation \& Services.: New Conceptual Frameworks" CRIC Discussion Paper 38. Manchester: CRIC

[14] Innosight Consulting Firm (2005). Disruptive Innovation Primer

[15] Jeston, J, \& Neilis, J. (2006). Sydney: A BPTrends Column

[16] Kotler, P., Armstrong G., Saunders J., \& Wong P. (2002). Principles of Marketing. ( $3^{\text {rd }}$ edn.)

[17] LENFLE Sylvain (2004) "Peut-on gérer l'innovation par projet ?" in GAREL Gilles, GIARD Vincent, MIDLER Christophe [eds.] Faire de la recherche en management de projet, Paris, Vuibert Fnege, pp. 11-34.

[18] Lovelock, C., \& Wirtz J. (2007). Service Marketing.: people, technology, strategy. ( $6^{\text {th }}$ edn.). New Jersey: Prentice Hall

[19] Maffei S., Mager B. and Sangiorgi D., Innovation through Service Design. From Research and Theory to a Network of Practice. A users' driven perspective, Joining Forces Conference, 21-23 September, Helsinki, 2005

[20] Nählinder, J. (2005). Innovation and Employment in Services. The case of Knowledge Intensive Business Services in Sweden. Linköping: Linköping University 
[21] Pariag, P. (2009). Classification of Services. Regional Symposium on Services 15-17 July 2009 Grand Royal Antiguan Beach Resort Antigua and Barbuda

[22] Preissl, B. (1997). Services in Europe. Patterns of Growth and Development. SI4S survey paper 2. Oslo: STEP

[23] Rogers, E. (1995). Diffusion of innovations. (4th edn.). New York, NY: The Free Press

[24] Sasser, W.E., Olsen, R.P., \& Wyckoff, D.D. (1978). Management of Service Operations.: Text and Cases. Boston: Allyn \& Bacon
[25] Stanton, W.J. (1981). Fundamentals of marketing. $\left(6^{\text {th }}\right.$ edn.). USA: McGraw-Hill. pp 446, 444, 441

[26] Susman G., Warren A. and Ding M. (2006), Product and Service Innovation in Small and Medium-Sized Enterprises, State College, Pennsylvania, Smeal College of Business; report to The National Institute of Standards and Technology (United States Department of Commerce) RFP 05-480-5824 Available

http://www.smeal.psu.edu/cmtoc/research/nistnpd.pdf

[27] Van Ark, B. Broersma, L. and Den Hertog, P. (2003) Service Innovation, Performance and Policy: A Review , Ministry of Economic Affairs, The Hague 